\title{
An Analytical Study of Long Term Rainfall Variability of Washim (Maharashtra), India Using GIS
}

\author{
Sudarshan Awatade ${ }^{1 *}$, Sumedh R. Kashiwar ${ }^{2}$, Souvik Ghosh ${ }^{1}$, R.B. \\ Singhandhupe $^{3}$ and Usha R. Dongarwar ${ }^{4}$
}

${ }^{1}$ Department of Agricultural Extension, ${ }^{2}$ Department of Soil Science and Agricultural Chemistry, Palli Shiksha Bhavana (Institute of Agriculture), Visva-Bharati, Sriniketan, West-Bengal, India-731236

${ }^{3}$ Agronomy, Central Institute for Cotton Research, Nagpur, Maharashtra, India-441108

${ }^{4}$ Krishi Vigyan Kendra, Sakoli, Bhandara, Maharashtra, India-441802

*Corresponding author

\begin{abstract}
A B S T R A C T
The study of rainfall variability is very crucial in the tropical country like India where agriculture sector shared 17-18 percent to the country's GDP. As rainfall having direct

Keywords

Long term, Rainfall,

Variability,

Washim,

GIS

\section{Article Info}

Accepted:

06 July 2018

Available Online:

10 August 2018 relationship with agriculture, change in rainfall patterns reveals direct effects on agricultural production and success or failure of cropping patterns countrywide. Hence, it is obligated to have precise knowledge of rainfall for disaster management, hydrological planning, economic development etc. So, the present study attempts to analyze monthly, seasonal and annual rainfall pattern using data series of 11 years (2007-2017) to get the spatial variability and temporal trends from six sub divisions of Washim, Maharashtra, India. Result shows the mean annual rainfall for the district as $796.96 \mathrm{~mm}$, station wise ranges from $888.8 \mathrm{~mm}$ (Washim) as highest to $742.2 \mathrm{~mm}$ (Karanja) as lowest during 20072017. The month of July and August has proved very good for farmers contributing more to the average annual rainfall of the district. But, significantly high range of rainfall variability is observed in overall parts of the district during the first five months of the year that may result in increase in heating, water scarcity and lowering the ground water level. To cope with this type of agriculture related problems, it is essential to assess in advance the trend of future climatic variability based on past experiences. The present study will help to find out possible reason for the increasing water scarcity and will definitely provide a guideline for the researchers for sustainable development of water resources over all Washim district.
\end{abstract}

\section{Introduction}

Worldwide agriculture is sensitive to shortterm changes in weather and to seasonal, annual and longer-term variations in climate. For the long-term changes, agriculture is able to tolerate moderate variations in the climatic mean. The variations in the meteorological 
parameters have overriding influence on the agricultural systems, although other parameters, like soil characteristic, seed genetics, pest and disease and agronomic practices also do impact crop yields. It is widely believed that developing countries such as India will be impacted more severely than developed countries. Where, about 56\% of the net cultivated area of the country is rain-fed that largely depends on monsoon rainfall, accounting for $44 \%$ of food production contributing17-18 percent to the country's GDP. Thus Monsoon rainfall is crucial for agriculture production and food security as well as economic development of the country. India is a tropical country, its agricultural planning and utilization of water is depends mostly on monsoon rainfall, that replenishes soil moisture, stream flows, lakes, etc. Country receives about $80 \%$ of its total rainfall during the monsoon season from June to September, mainly the heavy rainfall occurs during this season, but unevenly both in time and space, that makes it significant factors to evolving the rainfall analysis (Ghosh et al., 2009; Rajapange and Wani, 2011; Deulkar et al., 2015; Srividya and Gobu, 2017). Among the climatic elements, the rainfall is most crucial index, ever thought of by farmers and climatic analyzers, which effects directly to the agricultural production, cropping pattern or determines the type of crop to be cultivated and its success or failure in particular. Day by day the atmospheric temperature is increasing due to global warming and climate changes that are attributed towards the variability in rainfall, which is predominantly responsible for flood and drought conditions in many areas of the country. The three main characteristics of rainfall those are very necessary to know are, amount, frequency and intensity, the values of which vary from place to place, day to day, month to month and also year to year. Exact knowledge of these three main characteristics is obligatory for planning and its full utilization. However, knowledge on the spatial variability and temporal trends of mean rainfall is essential for efficient management of water resource and agriculture. Several researchers have studied the distribution, variability and trends of rainfall at global, regional and basinal scales (for example, Soltani et al., 2007; Krishnakumar et al., 2008; Anandakumar et al., 2008; Guhathakurta and Rajeevan, 2008; Zhang et al., 2009; Sivapragasam et al., 2013; Chakraborty et al., 2013; Deulkar et al., 2015). The study by Guhathakurta and Rajeevan (2008) has clearly revealed the existence of significant changes in the rainfall pattern over meteorological subdivisions of India for the monsoon months and seasons. Krishnakumar et et al., (2008) studied temporal (monthly, seasonal and annual) rainfall trends in twentieth century over Kerala, India and reported a significant decrease of rainfalls during the southwest monsoon and an increase during the postmonsoon season. Guhathakurta and Saji (2013) studied trends in long rainfall data series (1901- 2006) of districts of Maharashtra, India, in temporal (monthly, seasonal and annual) and reported a increasing trends in monsoon rainfall in many areas, where the decreasing trends in the first five months of the year have resulted in increase in heating, and may have an effect in the shortage of soil moisture, ground water and lowering the ground water level. As well delay in onset of South-West Monsoon, Long 'break' during the of South-West Monsoon season, insufficient rains and skewed spatial distribution particularly during June and July and fall in the level of reservoirs that leads the majority of the human, farmers and livestock population to suffer scarcity of water mostly throughout the year (Drought Crisis Management Plan, GOI, 2017). Study of Deulkar et al., (2015) in Vidarbha region of Maharashtra, India by using trend analysis revealed reduced rainfall in the last 60 years. It is clear from the seasonality index that 
Washim district of Vidarbha region of Maharashtra, India is dry region with 650-850 $\mathrm{mm}$ rainfall less as compare to other regions of Maharashtra, India. Therefore, the present study has focuses on the spatial and temporal variability and trends of summer monsoon rainfall in more details over Washim district of Maharashtra, India by using data sets covering the period 2007 to 2017.

\section{Materials and Methods}

Present study was carried out in the Washim district of Maharashtra, India which comprises six sub divisions namely Washim $\left(77.191287^{\circ} \mathrm{E} 20.087518^{\circ} \mathrm{N}\right)$, Karanja $\left(77.513479^{\circ} \mathrm{E} \quad 20.550669^{\circ} \mathrm{N}\right), \quad$ Mangrulpir $\left(77.346789^{\circ} \mathrm{E} \quad 20.310143^{\circ} \mathrm{N}\right), \quad$ Malegaon $\left(77.015647^{\circ} \mathrm{E} \quad 20.278819^{\circ} \mathrm{N}\right), \quad$ Manora $\left(77.545922^{\circ} \mathrm{E} \quad 20.207221^{\circ} \mathrm{N}\right)$ and Risod $\left(76.789665^{\circ} \mathrm{E} 20.029344^{\circ} \mathrm{N}\right)$. The district is basically agriculture oriented with varied topographical climatological features, categorized under two agro climatic zone type viz. Assured rainfall zone (ACZ-7) and Moderate Rainfall Zone (ACZ-8).

Where, Risod and Karanja tehsils falls under Assured rainfall zone (ACZ-7) covering 170583 ha area and Washim, Malegaon, Manora and Mangrulpir tehsils falls under Moderate Rainfall Zone (ACZ-8) covering 342541 ha area. The study aimed to examine the considerable long term changes in monthly rainfall in the district by trend analysis of rainfall time series. Monthly rainfall data of six rain gauge stations of Washim district (Table 1) from 2007-2017 were taken from the Indian meteorological department (IMD), Pune, India. The monthly and seasonal scales are constructed and then mean rainfall and coefficient of variability are analyzed to get the spatial pattern and variability. The base map has been prepared from the Survey of India Topographic sheets on 1:50,000 scale. The collected rainfall data has been processed and analyzed by using GIS software and relevant maps have been prepared using the ArcGIS software. It was found that the inverse squared distance method in GIS software gave better results compared to the other interpolation methods (kriging function). In this method, the weighted rainfall is calculated from the rain gauge data by its distances from the interpolating point. This helps in improving the accuracy of the spatial interpolation in regions having low density of rain gauge networks.

\section{Results and Discussion}

The data of six weather stations from 11 years (2007-2017) has been taken to analyze the spatial distribution and its characteristics of the study area (Table 1 and Fig. 1).

The mean annual rainfall for the district has been recorded as $796.96 \mathrm{~mm}$, whereas station wisemean annual rainfall ranges from 888.8 $\mathrm{mm}$ (Washim) as highest to $742.2 \mathrm{~mm}$ (Karanja) as lowest during the year 2007-2017 (Table 2, Fig. 2-12) with large variation in rainfall and its distribution. The highest rainfall has recorded at Washim weather station $(888.8 \mathrm{~mm})$ where river Arunavati and its tributaries originates and then flows through the tehsils of Mangrulpir and Manora into the district of Yavatmal. Mangrulpir station is situated to the central part of the study area where somewhat similar effects has been recorded with $845.1 \mathrm{~mm}$ of rainfall during 2007-2017 (Table 2, Fig. 2-12). Whereas Risod and Malegaon weather station has received $769.9 \mathrm{~mm}$ and $783.2 \mathrm{~mm}$ of rainfall during 2000-2017 respectively. And the lowest annual rainfall mean has been recorded at Karanja $(742.2 \mathrm{~mm})$ weather station, located in the north east parts of the study area followed by Manora $(752.6 \mathrm{~mm})$ station situated to east parts of the study area. Only three weather stations (Washim, Mangrulpir and Malegaon) has received the 
high mean annual rainfall $(780 \mathrm{~mm}$ to 880 $\mathrm{mm}$ ) respectively (Table 2, Fig. 2-12). On an average of eleven years rainfall data, out of 12 months, month of July and August has proved very good for the farmers of the study area as the average rainfall received in these months
(244.12 $\mathrm{mm}$ and $190.25 \mathrm{~mm}$ respectively)shared great contribution to the average annual rainfall of the district. However, the average rainfall for the month of December and January and May are noticed to be negligible (Table 2).

\begin{tabular}{|l|l|l|}
\hline \multicolumn{2}{|c|}{ Table 1. Weather Data Stations } \\
\hline Sr. No. & Station & Geo-location \\
\hline $\mathbf{1}$ & Washim & $77.191287^{\circ} \mathrm{E} 20.087518^{\circ} \mathrm{N}$ \\
\hline $\mathbf{2}$ & Risod & $76.789665^{\circ} \mathrm{E} 20.029344^{\circ} \mathrm{N}$ \\
\hline $\mathbf{3}$ & Malegaon & $77.015647^{\circ} \mathrm{E} 20.278819^{\circ} \mathrm{N}$ \\
\hline $\mathbf{4}$ & Mangrulpir & $77.346789^{\circ} \mathrm{E} 20.310143^{\circ} \mathrm{N}$ \\
\hline $\mathbf{5}$ & Manora & $77.545922^{\circ} \mathrm{E} 20.207221^{\circ} \mathrm{N}$ \\
\hline $\mathbf{6}$ & Karanja & $77.513479^{\circ} \mathrm{E} 20.550669^{\circ} \mathrm{N}$ \\
\hline
\end{tabular}

Season wise Mean Rainfall Pattern and Variability

Table 3- Season wise variations in mean rainfall at six stations (2007-2017)

\begin{tabular}{|c|c|c|c|c|}
\hline Station & Winter & Pre-Monsoon & Monsoon & Post-Monsoon \\
\hline \multicolumn{5}{|l|}{ Washim } \\
\hline Average & 5.08 & 13.50 & 824.72 & 45.54 \\
\hline Standard deviation & 12.90 & 26.95 & 387.76 & 62.44 \\
\hline Coefficient of variation & 253.81 & 199.63 & 47.02 & 137.11 \\
\hline \multicolumn{5}{|l|}{ Risod } \\
\hline Average & 3.04 & 9.98 & 724.09 & 32.77 \\
\hline Standard deviation & 8.26 & 22.42 & 313.82 & 43.25 \\
\hline Coefficient of variation & 271.88 & 224.58 & 43.34 & 131.96 \\
\hline \multicolumn{5}{|l|}{ Malegaon } \\
\hline Average & 4.59 & 14.30 & 718.76 & 45.53 \\
\hline Standard deviation & 10.37 & 30.58 & 366.05 & 62.54 \\
\hline Coefficient of variation & 225.78 & 213.88 & 50.93 & 137.37 \\
\hline \multicolumn{5}{|l|}{ Mangrulpir } \\
\hline Average & 6.50 & 26.12 & 763.59 & 48.85 \\
\hline Standard deviation & 15.86 & 48.02 & 401.20 & 71.63 \\
\hline Coefficient of variation & 243.99 & 183.84 & 52.54 & 146.61 \\
\hline \multicolumn{5}{|l|}{ Manora } \\
\hline Average & 4.71 & 9.30 & 699.05 & 39.54 \\
\hline Standard deviation & 11.66 & 20.23 & 397.51 & 67.05 \\
\hline Coefficient of variation & 247.59 & 217.44 & 56.86 & 169.60 \\
\hline \multicolumn{5}{|l|}{ Karanja } \\
\hline Average & 4.69 & 15.90 & 674.09 & 47.50 \\
\hline Standard deviation & 11.03 & 32.38 & 295.66 & 59.04 \\
\hline Coefficient of variation & 235.20 & 203.65 & 43.86 & 124.30 \\
\hline
\end{tabular}


Table.2 Station wise average annual rainfall distribution (2007-2017)

\begin{tabular}{|l|l|l|l|l|l|l|l|l|l|l|l|l|l|}
\hline Station & Jan & Feb & Mar & Apr & May & Jun & Jul & Aug & Sep & Oct & Nov & Dec & Annual \\
\hline Washim & 4.25 & 0.84 & 4.92 & 8.58 & 0.00 & 186.90 & 256.47 & 204.35 & 177.00 & 34.83 & 10.71 & 0.00 & 888.84 \\
\hline Risod & 1.10 & 1.94 & 3.00 & 6.98 & 0.00 & 165.85 & 231.02 & 172.16 & 155.05 & 24.39 & 8.38 & 0.00 & 769.88 \\
\hline Malegaon & 4.45 & 0.14 & 8.13 & 6.17 & 0.00 & 158.41 & 226.05 & 194.91 & 139.39 & 36.35 & 9.18 & 0.00 & 783.18 \\
\hline Mangrulpir & 5.58 & 0.92 & 14.35 & 11.76 & 0.00 & 160.27 & 275.28 & 211.66 & 116.37 & 39.28 & 9.57 & 0.00 & 845.06 \\
\hline Manora & 3.78 & 0.93 & 6.12 & 2.55 & 0.64 & 164.96 & 223.92 & 192.70 & 117.47 & 28.40 & 11.14 & 0.00 & 752.60 \\
\hline Karanja & 3.15 & 1.54 & 11.05 & 4.85 & 0.00 & 134.14 & 251.96 & 165.74 & 122.25 & 37.95 & 9.55 & 0.00 & 742.18 \\
\hline District & 3.72 & 1.05 & 7.93 & 6.82 & 0.11 & 161.76 & 244.12 & 190.25 & 137.92 & 33.53 & 9.76 & 0.00 & 796.96 \\
\hline
\end{tabular}

Fig.1 Study area location map
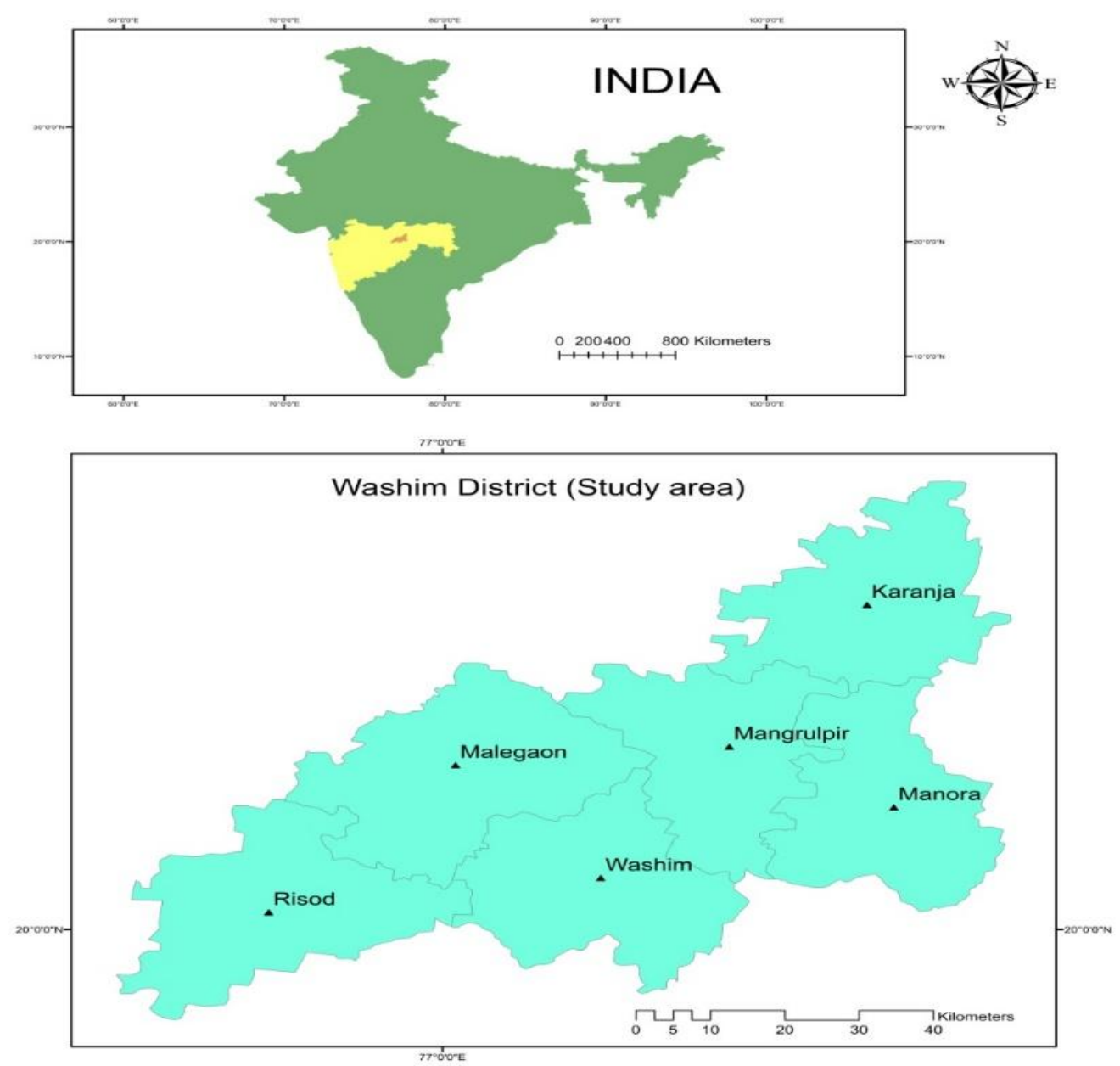
GIS based Maps of Mean of Annual Rainfall Distribution at Six Weather Stations of Washim District (2007-2017)

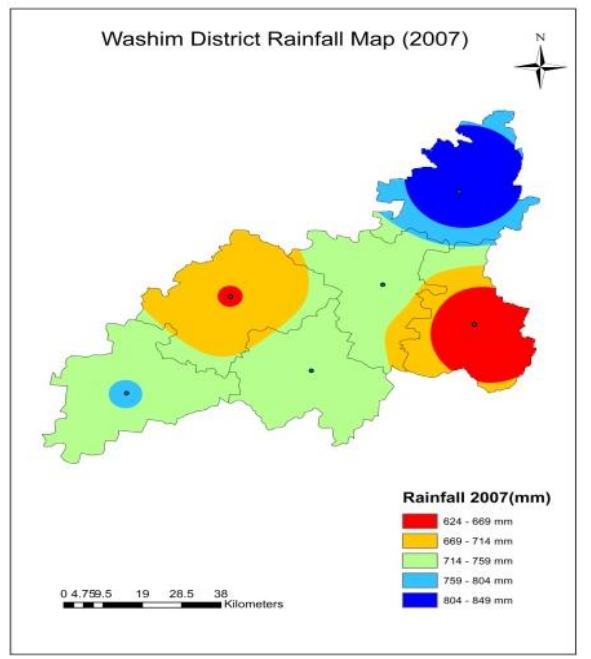

Fig. 2: Mean Annual Rainfall (2007)

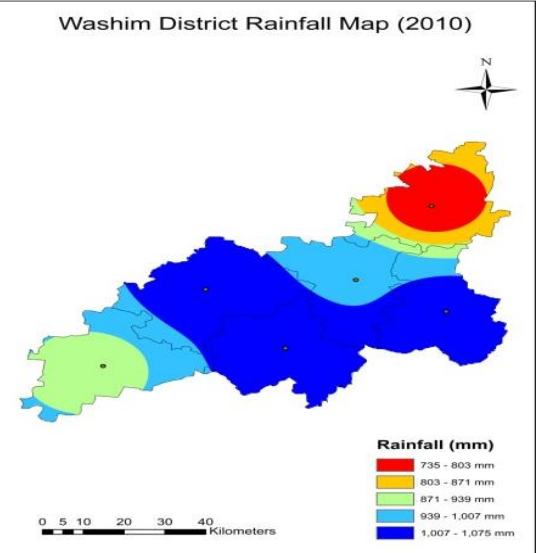

Fig. 5: Mean Annual Rainfall (2010)

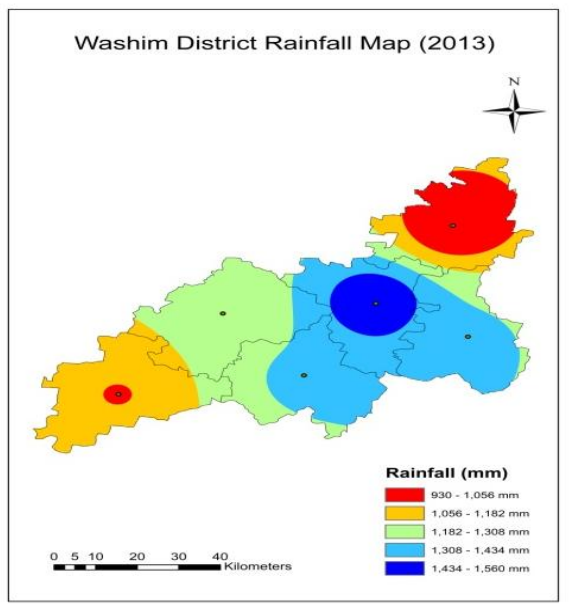

Fig. 8: Mean Annual Rainfall (2013)

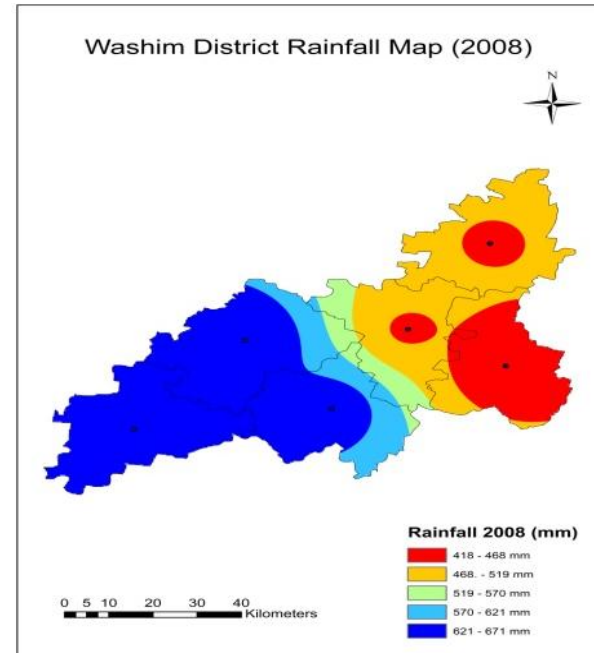

Fig. 3: Mean Annual Rainfall (2008)

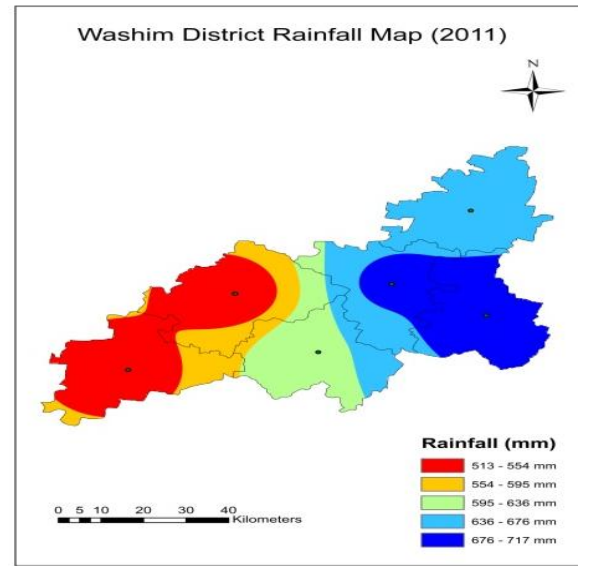

Fig. 6: Mean Annual Rainfall (2011)

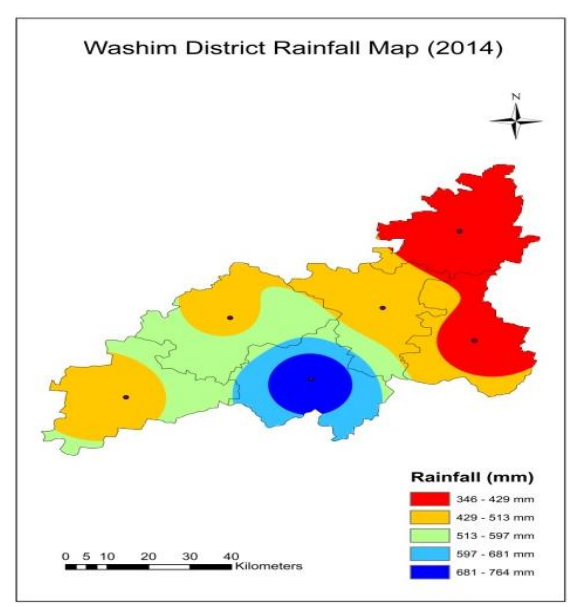

Fig. 9: Mean Annual Rainfall (2014)

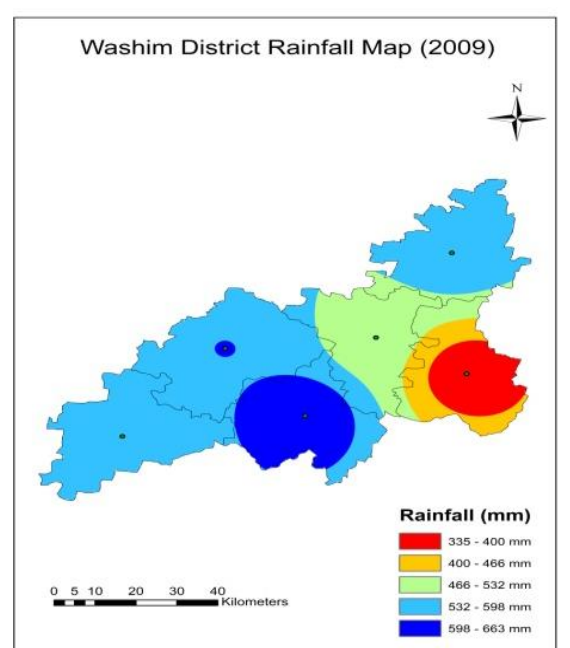

Fig. 4: Mean Annual Rainfall (2009)

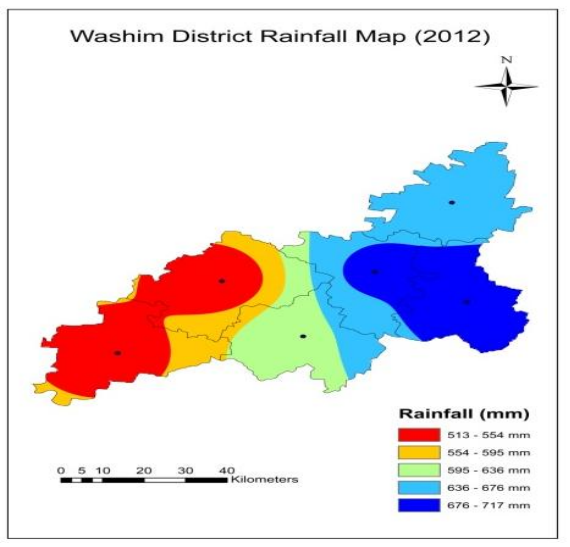

Fig. 7: Mean Annual Rainfall (2012)

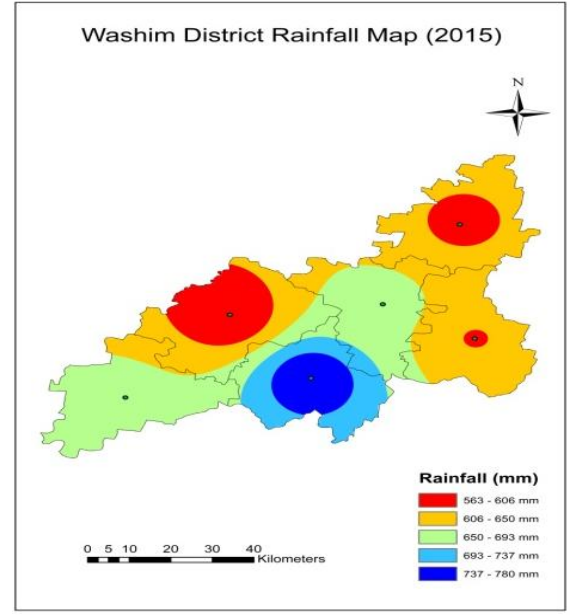

Fig.10: Mean Annual Rainfall (2015) 


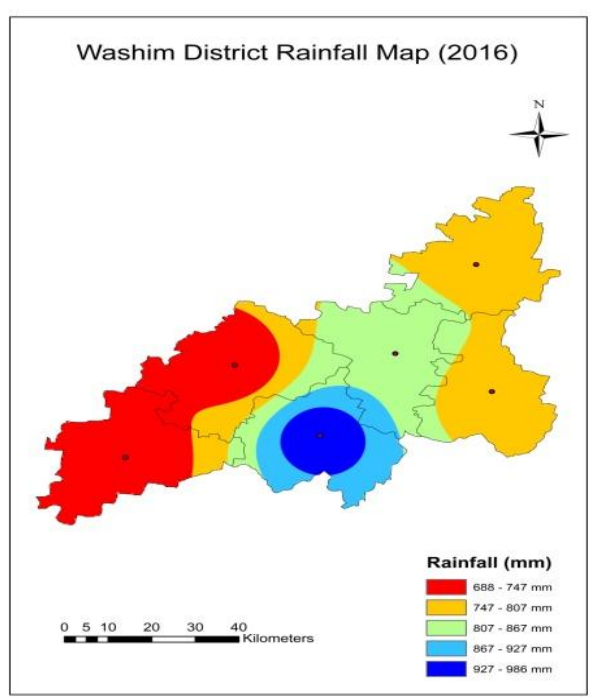

Fig.11: Mean Annual Rainfall (2016)

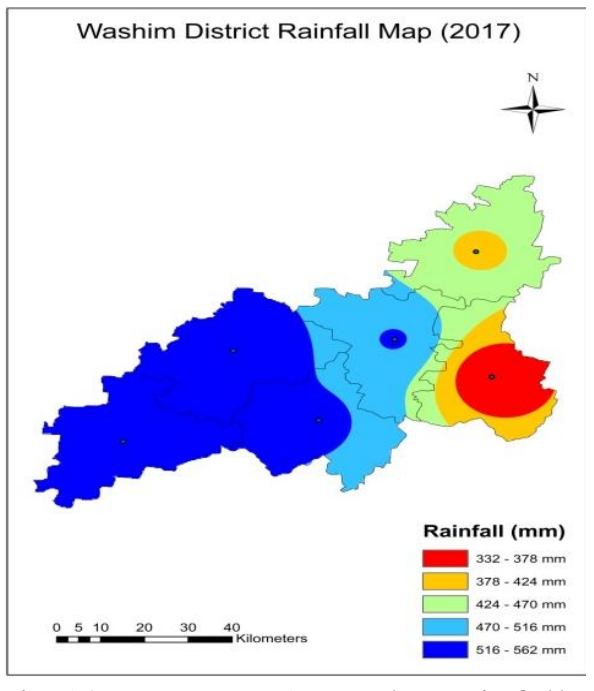

Fig.12: Mean Annual Rainfall (2017)

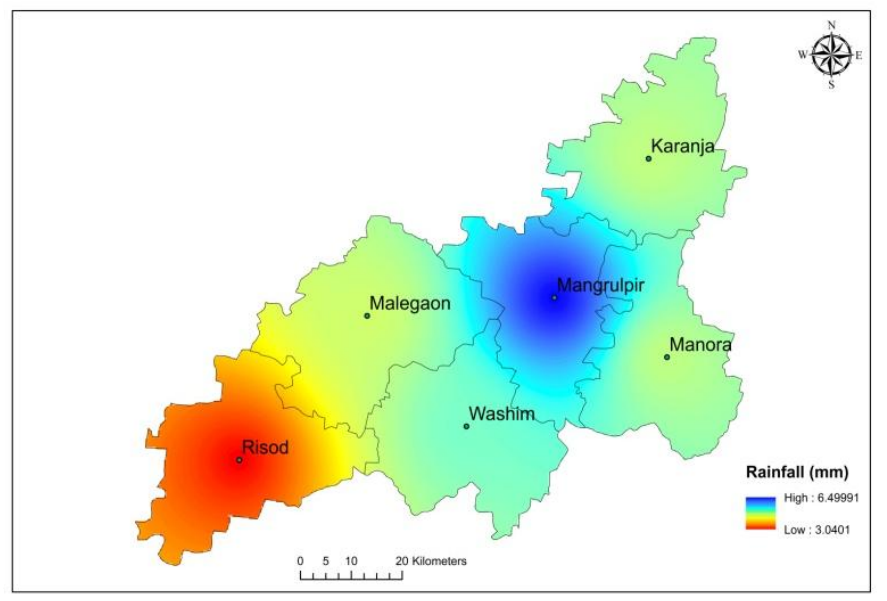

Fig.13: Rainfall Distribution (Winter)

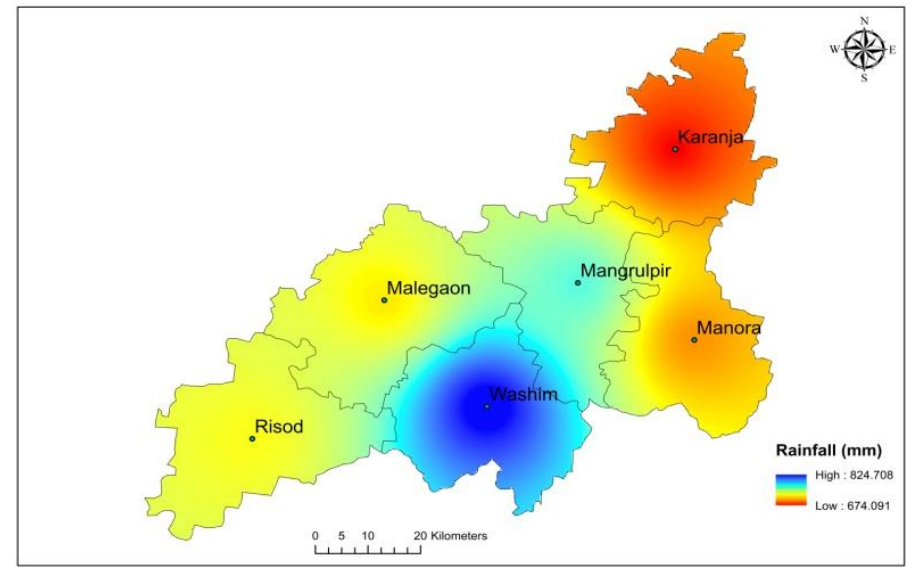

Fig.15: Rainfall Distribution (Monsoon)

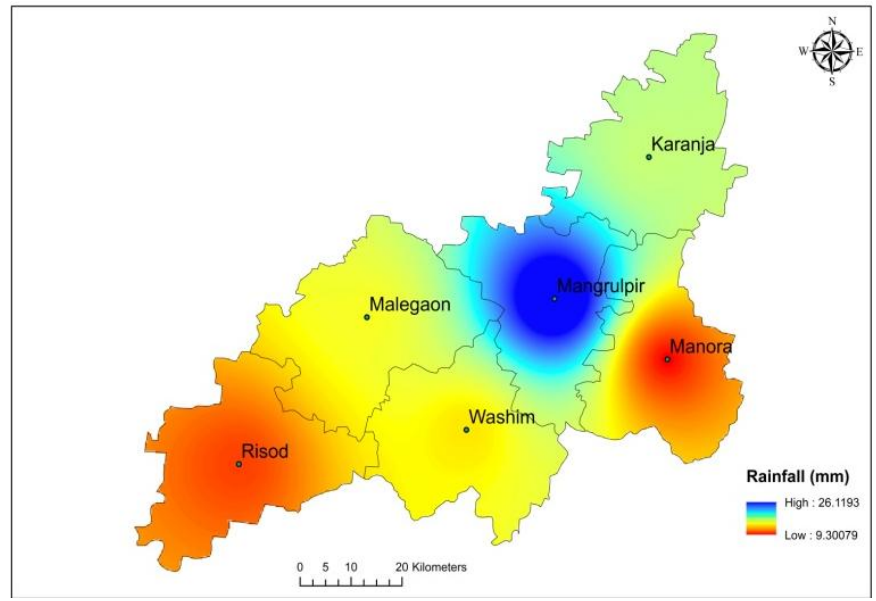

Fig.14: Rainfall Distribution (Pre-Monsoon)

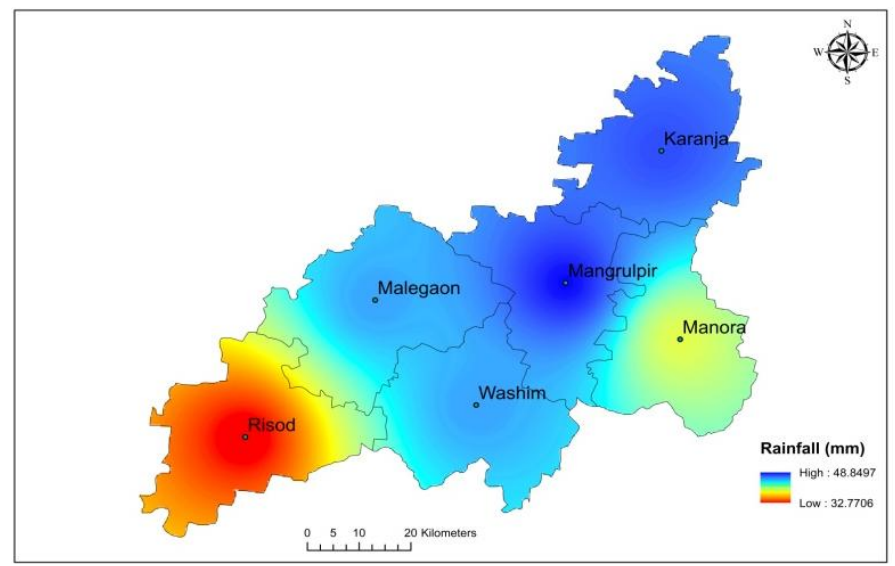

Fig.16: Rainfall Distribution (Post-Monsoon) 
During the winter season (January-February), all the weather stations of the district received very low rainfall (even much less than $6 \mathrm{~mm}$ ). Only the Mangrulpir station in the central part of the district received rainfall above $6 \mathrm{~mm}$ i.e. $6.50 \mathrm{~mm}$. Whereas lowest is observed at Risod station in south western part of the district with only $3.04 \mathrm{~mm}$ of rainfall (Table 3, Fig. 13). During winter seasons, country (mostly northern parts) gets rainfall due to western disturbances and southern parts due to easterly waves. As a result, eastern parts of the district get some rain whereas western parts receive negligible amount of rain. Both in winter and pre- monsoon seasons, maximum rainfall is received by Mangrulpirweather station (Table 3, Fig. 13 and 14). And the lowest is noticed in the Manora weather station with average rainfall of $9.30 \mathrm{~mm}$. The maximum rainfall zone has shifted from eastern parts of the district to south western parts in monsoon season (JunSept). The maximum rainfall of $824.72 \mathrm{~mm}$ is being received by Washim station followed by Mangrulpir station (763.59 $\mathrm{mm})$. However, mean rainfall for the other stations are between 650 and $750 \mathrm{~mm}$ where, Karanja station have experienced lowest average rainfall as $674.09 \mathrm{~mm}$ during the months monsoon season. The northeast monsoon (post-monsoon) is very active during the months of October, November and December. The northeast monsoon rainfall varies from $48.85 \mathrm{~mm}$ at Mangrulpir to $32.77 \mathrm{~mm}$ at Risod weather stations, which are located in the north and the west parts respectively (Table 3, Fig. 16). The changing pattern of maximum rainfall zone, i.e., initially at the central parts, then concentrated at the central part (Mangrulpir)with slightly northern movementin pre-monsoon followed by suddenly quick movement towards southern in monsoon season and remaining there in post-monsoon where south western part immensely received low rainfall can be clearly seen by comparing Figure 13, 14, 15 and 16. These all figures shown mean annual rainfall pattern over the different stations of Washim districts of Maharashtra, India for four seasons. In addition to mean rainfall pattern, the knowledge of variability of rainfall is also of great use for hydrological planning and management. In Table 3 the values of coefficient of variation clearly represents the rainfall variability over spatial distribution for the four. Scanty rainfall is being received during the winter season (Jan and Feb) and the variability is very high i.e., above $200 \%$ at all the stations of Washim district. Maximum variability $(271.88 \%)$ is over Risod station and the lowest variability $(225.78 \%)$ is over Malegaon station. In premonsoon season (starting March up to the end of May) all the stations of Washim district have recorded high variability of rainfall $(\geq$ $200 \%$ ) except Mangrulpir station (183.84 \%). During both the seasons of winter and premonsoon almost all parts of the district have to face high variability in rainfall (> $200 \%)$ but as the monsoon set in the variability has decreased and again it increased in the postmonsoon season. During monsoon season, coefficient of variability of monsoon rainfall is observed highestatManora station $(>55 \%)$ with lowest received rainfall. Even during the post- monsoon season also the Manora station had to face less amount of rainfall with highest variability(169.60 \%) followed by Mangrulpir station where, in spite of very high rainfall, coefficient of variability of monsoon rainfall is observed high $(>140 \%)$ and variability in rainfall at other remaining stations noticed between (125 to $145 \%$ ).

It is concluded on an average of eleven years rainfall data, out of 12 months, month of July and August has proved very good for the farmers of study area as the contribution of average rainfall in July and August is more to the average annual rainfall of the district. But the significant high range of rainfall variability is observed in overall parts of the 
district during the first five months of the year that may result in increase in heating and may have an effect in water scarcity and lowering the ground water level in study area. The variability in the average rainfall for all four seasons of winter, pre-monsoon, monsoon and post-monsoon is diverse in the region. In summer season the region is experiencing long dry breaks resulting in rise of temperature where sudden rainfall leads to summer horticultural crop damages. The rainfall variability is the most significant phenomenon affecting almost agricultural sector of the region as the major part of the region is rainfed. Variability also poses problems before farmers to adopt certain measures as they may become useless after one cycle of variability. The uneven rainfall pattern and low precipitation in rainfed region even during rainy season leads the farmers to take wrong measures. To cope with the agriculture related problems, it is essential to assess in advance the trend of future climatic variability based on past experiences.

\section{References}

Anandakumar, S., Subramanp, T., Elango I. (2008). Spatial Variation and Seasonal behaviour of rainfall pattern in Lowerbhavani river basin, Tamil Nadu, India. IntBiannu J Environ Sci (The Ecoscan 2):17-24

Chakraborty, S et al (2013). Trend and variability analysis of rainfall series at Seonath River Basin, Chhattisgarh (India). Int $J$ ApplSci Eng Res 2(4):425-434

Deulkar, A. M., Dixit, P. R. and Kulkarni, H. (2015). Trends in Rainfall Pattern over Vidarbha Region of Maharashtra State, India. International Journal of Modern Trends in Engineering and Research. 7 (2), 700-707.

Diouf, R., Sambou, H., Traore, V. B., Ndiaye, M. L., Chaibo, A., Sambou, B., Diaw,
A. T. and Beye, A. C. (2016). Frequency Analysis and Exploratory of Rainfall Variability in Bounkiling River Basin in a Context of Climate Change and Variability, American Journal of Engineering Research (AJER), 11 (5), 82-93.

Drought Crisis Management Plan (2017). Department of Agriculture and Farmers Welfare, Government of India.

Ghosh, S., Luniya V. and Gupta, A. (2009). Trend analysis of Indian summer monsoon rainfall at different spatial scales. Atmospheric science letters, 285-290.

Guhathakurta, P., and Rajeevan, M. (2008) Trends in the rainfall pattern over India. Int J Climatol 28:1453-1469.

Guhathakurta, P., and Saji, E. (2013). Detecting changes in rainfall pattern and seasonality index vis- a-vis increasing water scarcity in Maharashtra. J. Earth Syst. Sci.122 (3), 639-649.

Guhathakurta, P., Sreejith, O. P., and Menon, P. A. (2011). Impact of climate change on extreme rainfall events and flood risk in India. J. Earth Syst. Sci. 120(3) 359-373.

Krishnakumar, KN, Prasada Rao GSLHV, Gopakumar, CS (2008) Rainfall trends in twentieth century over Kerala, India. Atmos Environ 43:1940-1944.

Rajapange, M. G., Wani, P. R. (2011). A Geographical Study of Rainfall Distribution in Beed District (M.S.), Hi-Tech Research Analysis, Vol. 1, Issue, pp 70-75.

Ramesh Kumar, M. R., Krishnan, R., Sankar, S., Unnikrishnan, A. S., and Pai, D. S. (2009) Increasing trend of "breakmonsoon" conditions over India-role of ocean-atmosphere processes in the Indian Ocean. IEEE Geosci. Remote Sensing Lett. 6(2), 332-336. 
Singh, R. B., Singh, A., and Kumar, A. (2014). Climate Change Variability in Coastal Karnataka, India. Climate Change and Biodiversity: Proceedings of IGU Rohtak Conference Vol. 1, Advances in Geographical and Environmental Sciences, 978-4-43154837-9: 15-26.

Sivapragasam, C et al (2013) Trends in rainfall patterns over the Tamarabarani basin in Tamil Nadu, India. In: 20th international congress on modelling and simulation, Adelaide, Australia.

Soltani, S., Modarres, R., Eslamian, S. S.
(2007). The use of time series modeling for the determination of rainfall climates of Iran. Int J Climatol 27:819-829.

Srividya, C., and Gobu, B. (2017). Analysis of Rainfall Variation Using GIS: The Ambuliyar Watershed, Tamil Nadu, India. International Journal of Development Research, 10 (07): 16331-16337

Zhang Q, Xu CY, Zhang Z, Chen YD, Liu CL (2009) Spatial and temporal variability of precipitation during 1951-2005 over China. Theor App Climatol 95:53-68

\section{How to cite this article:}

Sudarshan Awatade, Sumedh R. Kashiwar, Souvik Ghosh, R.B. Singhandhupe and Usha R. Dongarwar. 2018. An Analytical Study of Long Term Rainfall Variability of Washim (Maharashtra), India Using GIS. Int.J.Curr.Microbiol.App.Sci. 7(08): 860-869. doi: https://doi.org/10.20546/ijcmas.2018.708.097 